\title{
Origin of Cretaceous phosphorites from the onshore of Tamil Nadu, India
}

\author{
V Purnachandra RaO ${ }^{1, *}$, Pratima M Kessarkar ${ }^{1}$, \\ R NAGENDRA ${ }^{2}$ and E V S S K BABU ${ }^{3}$ \\ ${ }^{1}$ National Institute of Oceanography, Dona Paula, Goa 403 004, India. \\ ${ }^{2}$ Department of Geology, Anna University, Chennai 600 025, India. \\ ${ }^{3}$ National Geophysical Research Institute, Uppal Road, Hyderabad 500 007, India. \\ *e-mail:vprao@nio.org
}

\begin{abstract}
Cretaceous phosphorites from the onshore of Tamil Nadu have been investigated for their origin and compared with those in the offshore. Cretaceous phosphorites occur as light brown to yellowish brown or white nodules in Karai Shale of the Uttatur Group in the onshore Cauvery basin. Nodules exhibit phosphatic nucleus encrusted by a chalky shell of carbonate. The nucleus of the nodules consists of light and dark coloured laminae, phosphate peloids/coated grains and detrital particles interspersed between the laminae. Scanning electron microscope (SEM) studies reveal trapping and binding activity of microbial filaments. A mat structure with linearly arranged microbial filaments and hollow, cell-based coccoid cyanobacterial mat are present. Nodules contain abundant carbonate fluorapatite, followed by minor calcite, quartz and feldspar. The $\mathrm{P}_{2} \mathrm{O}_{5}$ content of the phosphorites ranges from 18 to $26 \%$. The $\mathrm{CaO} / \mathrm{P}_{2} \mathrm{O}_{5}, \mathrm{Sr}$ and $\mathrm{F}$ contents are higher than that of pure carbonate fluorapatite. Concentrations of $\mathrm{Si}, \mathrm{Al}, \mathrm{K}, \mathrm{Fe}$, and $\mathrm{Ti}$ are low. We suggest that the nuclei of the nodules represent phosphate clasts related to phosphate stromatolites formed at intertidal conditions. At high energy levels the microbial mats were disintegrated into phosphate clasts, coated with carbonate and then reworked into Karai Shale. On the other hand, Quaternary phosphorites occur as irregular to rounded, grey coloured phosphate clasts at water depths between 180 and $320 \mathrm{~m}$ on the continental shelf of Tamil Nadu. They exhibit grain-supported texture. Despite Quaternary in age, they also resemble phosphate stromatolites of intertidal origin and reworked as phosphate clasts onto the shelf margin depressions. Benthic microbial mats probably supplied high phosphorus to the sediments. Availability of excess phosphorus seems to be a pre-requisite for the formation of phosphate stromatolites.
\end{abstract}

\section{Introduction}

Cretaceous phosphorites represent one of the largest phosphogenic provinces through the geological record. Phosphorite deposits of the Uttatur Formation are a part of the extensive Cauvery basin sediments formed during the Cretaceous. The Cauvery basin is the southernmost part of the basin along the eastern margin of Peninsular India. It is a tectonic depression with an areal extent of $25,000 \mathrm{~km}^{2}$ and an almost equivalent area extending into the offshore waters of the Bay of Bengal up to $200 \mathrm{~m}$ isobath (Govindan et al 1998). Blanford (1862), followed by several others described the lithostratigraphy and biostratigraphy of the Cauvery basin and made remarks on the occurrence of phosphorite nodules (Rama Rao 1958; Mani et al 1966; Laskar and Narasimhan 1968; Sastry et al 1977; Govindan et al 1998). However, there is no detailed work on the origin and depositional environment of phosphorite. It is not clear how the nodules acquire carbonate

Keywords. Phosphate stromatolites; Cretaceous/Quaternary; petrology; geochemistry; Tamil Nadu, India. 
Table 1. Lithostratigraphic classification of Cretaceous sediments of the Cauvery Basin near Trichinopoly (Govindan 1998). Asterisks indicate the location of phosphorite nodules.

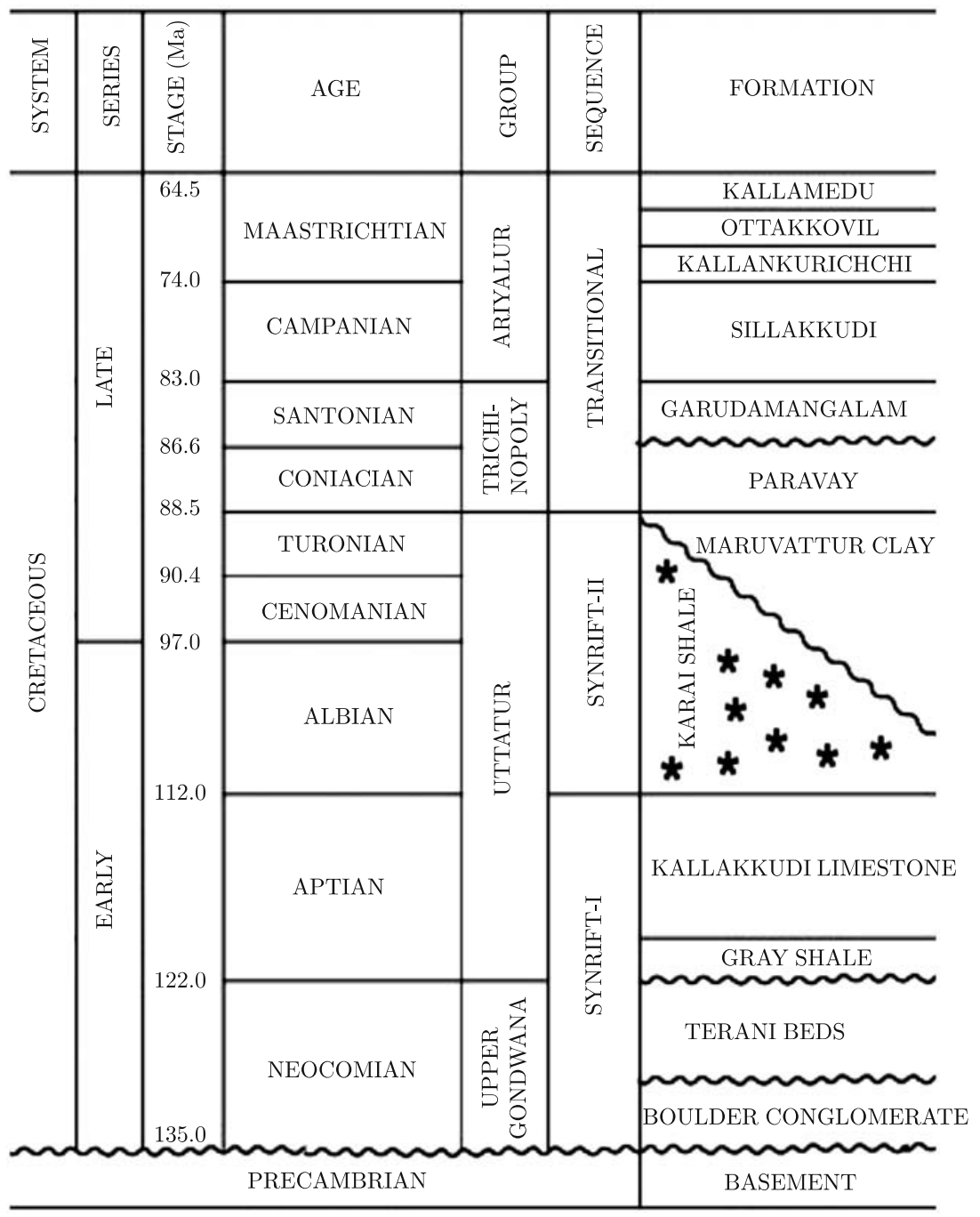

cortex if formed in shale sequences? On the other hand, Vaz (1995) was the first to report phosphorites on the outer continental shelf of Tamil Nadu. Subsequently, Vaz et al (1999) and Rao et al $(1998,2000,2002)$ carried out detailed investigations on the origin and depositional environment of phosphorite. Faunal elements such as larger bivalve and gastropod shells belonging to the Upper Cretaceous-Eocene age have been found to associate with offshore phosphorites at water depths between 180 and $320 \mathrm{~m}$ (Vaz et al 1999; Rao et al 2000). It is therefore important to establish the relationship between the onshore and offshore phosphorites in terms of their age, sources of phosphorus supply and processes of phosphogenesis. The purpose of this paper is to report detailed investigations on the origin of phosphorites in Uttatur Group of the onshore Cretaceous Cauvery basin and compare their characteristics with those in the offshore areas of Tamil Nadu.

\section{Geological setting and status of Cretaceous phosphorites}

The Cretaceous succession of the Cauvery basin developed on the Precambrian basement (table 1) during rifting and drifting phases of India after its separation from Australia and Antarctica. The Cretaceous Uttatur Group rests over the basement rocks and is divisible into three formations (Sastry et al 1977; Govindan et al 1998): Grey shale is the oldest formation, followed by Kallakkudi Limestone and Karai Shale/Maruavattur Clay. Phosphorite nodules are confined to the Karai Shale of late Albian-early-mid. Turonian age. Karai Shale is chocolate brown to rust yellowish clays and also consists of veins of gypsum, celestite and abundant belemnite guards. The lower contact of Karai Shale is conformable with Kallakkudi Limestone and unconformable with Archaen crystallites at places. The upper contact is, however, unconformable with 
the overlying Paravay Formation of Trichinopoly Group.

The Cretaceous period is an important episode of phosphogenesis with abundant phosphorite deposits distributed globally (Notholt et al 1986). The types of phosphorites, however, vary from laminated beds with intercalated glauconites, boulder conglomerates to nodular deposits, or graindominated to mud-dominated deposits. Phosphate peloids are a distinct component in several Cretaceous phosphorites. The origin of peloids, authigenic or reworked, is a matter of debate (Glenn 1990; Baioumy and Tada 2005). Furthermore, the dominant mechanism responsible for widespread phosphogenesis during the Cretaceous is yet to be evaluated. Reviews on phosphorites, however, suggest that there are three dominant processes that can explain the genesis of sedimentary phosphorites (Burnett and Riggs 1986; Notholt and Jarvis 1990; Follomi 1994). These include diagenetic precipitation from pore waters, replacement of carbonates at the sea floor by phosphates and precipitation by microbial activity and bacteria. Comparative studies revealed that though the onshore and offshore phosphorites belong to different geological periods, microbial processes played an important role in their formation.

\section{Materials and methods}

Phosphorite nodules were sampled from the Uttatur Group of the Karai Shale Formation near Trichinopoly (figure 1). Hard phosphorite nodules of different sizes (25 representative samples) were cut into two equal halfs, and one half was used to prepare thin sections and examined under a petrological microscope for their constituents and texture. The other half was used to prepare polished sections. Representative nodules (nucleus as well as outer layers separately) were powdered to fine size, and the powders were scanned from $8^{\circ}$ to $70^{\circ} 2 \theta$ at $1^{\circ} 2 \theta / \mathrm{min}$ on a Philips $1840 \mathrm{X}$-ray diffractometer using nickel filtered $\mathrm{Cu} \mathrm{K} \alpha$ radiation and identified the mineral phases. The freshly broken surfaces of ten phosphorite nodules were observed under JEOL 5800 LV scanning electron microscope (SEM) attached with EDS analyser facility at the National Institute of Oceanography, Goa. Two well-polished thin sections were used for major element geochemistry of phosphorites, using CAMECA Electron Probe Microanalyzer (EPMA) at the National Geophysical Research Institute, Hyderabad. A total of 100 points microprobe data on two thin sections were analysed and the average composition of the major elements and their correlation matrix are given in tables 2 and 3 , respectively.

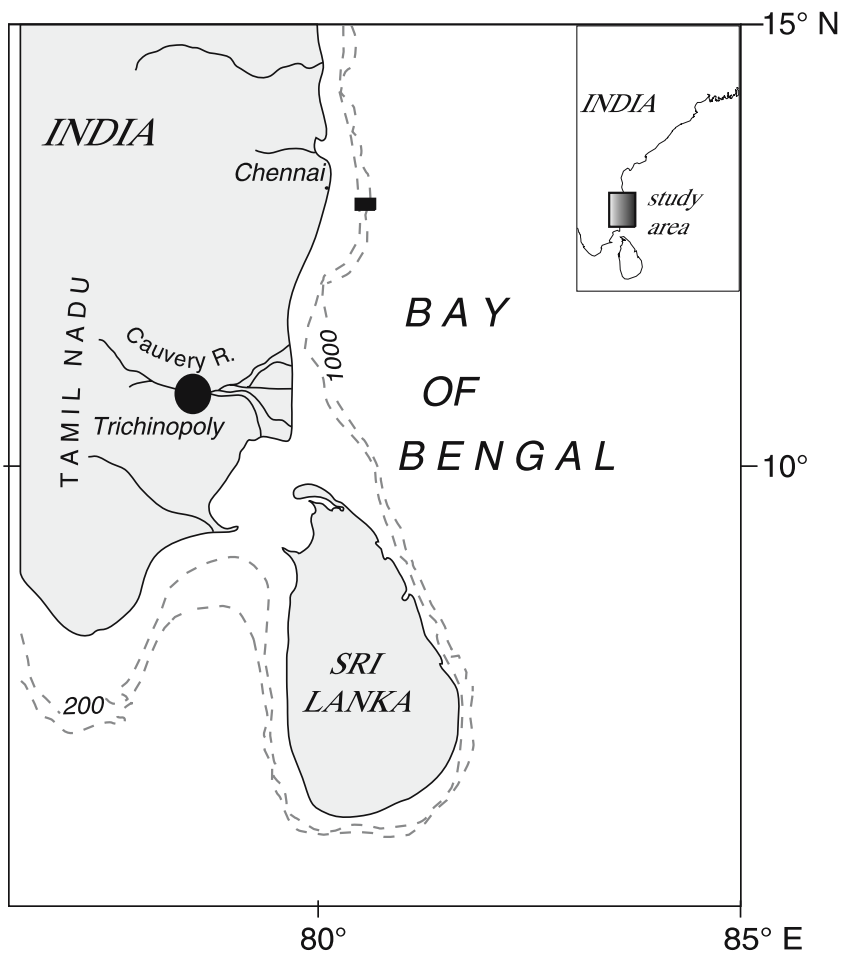

Figure 1. Map showing the location of the Cretaceous onshore (large solid circle) and Quaternary offshore (solid rectangle) phosphorites of Tamil Nadu, India.

\section{Results}

\subsection{Petrology of the Cretaceous phosphorites}

The Cretaceous phosphorites investigated here are nodular, $2-5 \mathrm{~cm}$ in diameter, hard, and light brown to yellowish brown or white in colour (figure 2A). Celestite crystals are encrusted on some nodules (figure 2B). Polished sections show that the nucleus is grey or dark brown in colour and dominantly phosphatic (figure $2 \mathrm{C}-\mathrm{E}$ ). The nucleus is encrusted by a yellowish to light brown chalky shell of carbonate. The larger nodules showed thicker carbonate shell and smaller nodules a thinner shell. The phosphatic teeth and bryozoan fragments are also encrusted by phosphate (figure $2 \mathrm{~F}-\mathrm{G}$ ). Thin veinlets of celestite or carbonate also occur both in the outer layers (figure $2 \mathrm{E}$ ) and within the micro-cracks of the nodules (figure $2 \mathrm{H}$ ). It is not always easy to separate nucleus from the cortex, especially in smaller nodules.

Thin sections of the nodules show that the nucleus consists of phosphate laminae, phosphate particles and silt size carbonates set in a structureless fine phosphate matrix. Planktonic foraminifers are rare constituents scattered in the matrix. Other carbonate particles are small and it is difficult to assign to a particular fossil. Light and dark layering is a characteristic feature of many 
Table 2. Microprobe analyses of onshore (Cretaceous) and offshore (Quaternary) phosphorites of Tamil Nadu.

\begin{tabular}{|c|c|c|}
\hline Element & $\begin{array}{c}\text { Onshore } \\
\text { phosphorites } \\
\text { (this study) } \\
(\%)\end{array}$ & $\begin{array}{c}\text { Offshore } \\
\text { phosphorites } \\
\text { (Rao et al } \\
2002)(\%)\end{array}$ \\
\hline $\mathrm{SiO}_{2}$ & $\begin{array}{c}1.8 \\
(0.12-5.92)\end{array}$ & 5.3 \\
\hline $\mathrm{Al}_{2} \mathrm{O}_{3}$ & $\begin{array}{c}2.7 \\
(0.02-4.79)\end{array}$ & 2.2 \\
\hline $\mathrm{Fe}_{2} \mathrm{O}_{3}$ & $\begin{array}{c}0.7 \\
(0.36-1.65)\end{array}$ & 2.6 \\
\hline $\mathrm{MgO}$ & $\begin{array}{c}0.2 \\
(0.36-1.65)\end{array}$ & 1.7 \\
\hline $\mathrm{CaO}$ & $\begin{array}{c}51.0 \\
(44.56-56.67)\end{array}$ & 49.0 \\
\hline $\mathrm{Na}_{2} \mathrm{O}$ & $\begin{array}{c}0.7 \\
(0.52-0.78)\end{array}$ & 0.1 \\
\hline $\mathrm{K}_{2} \mathrm{O}$ & $\begin{array}{c}0.1 \\
(0.01-0.2)\end{array}$ & 0.42 \\
\hline $\mathrm{P}_{2} \mathrm{O}_{5}$ & $\begin{array}{c}23.0 \\
(18.39-25.93)\end{array}$ & 30.9 \\
\hline $\mathrm{SrO}$ & $\begin{array}{c}0.3 \\
(0.11-0.41)\end{array}$ & 0.12 \\
\hline $\mathrm{SO}_{3}$ & $\begin{array}{c}0.9 \\
(0.42-1.22)\end{array}$ & NA \\
\hline $\mathrm{F}$ & $\begin{array}{c}5.2 \\
(3.64-6.31)\end{array}$ & NA \\
\hline $\mathrm{TiO}_{2}$ & $\begin{array}{c}0.1 \\
(0-0.65)\end{array}$ & NA \\
\hline
\end{tabular}

NA: not analysed.

samples (figure 3A). Light layers are composed of a nearly homogeneous phosphate ground mass with submicroscopic dark phosphatic particles, which appear mostly as agglutinated grains. Dark layers are phosphatic. There are layers resembling

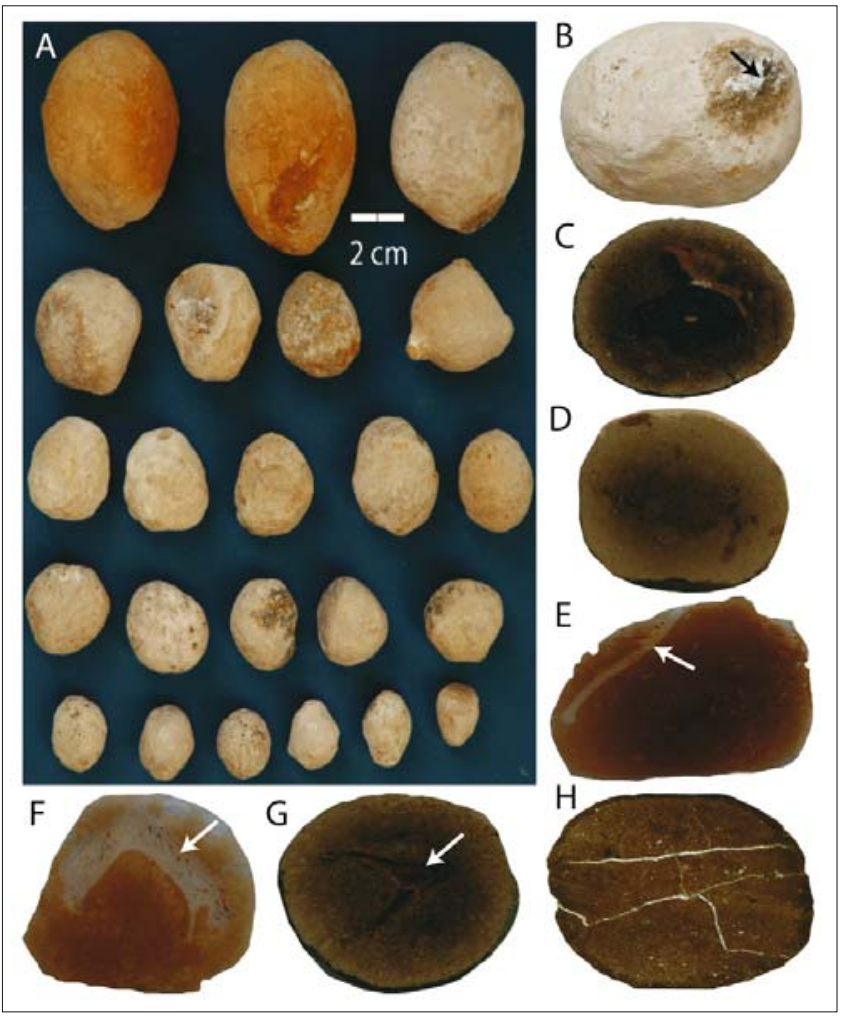

Figure 2. Photographs of Cretaceous phosphorites in the onshore Cauvery basin: (A) hand specimens; (B) selenite crystals (arrow) encrusted on nodule surface, $(\mathbf{C})-(\mathbf{H})$ polished sections: Arrow in ' $\mathrm{E}$ ' points to selenite filled crack, Arrows in ' $\mathrm{F}$ ' and ' $\mathrm{G}$ ' show bryozoan fragment and phosphatic teeth, respectively in the nodules.

algal laminae in which an organic mesh wraps over and around phosphate particles, peloids and detrital grains (figure $3 \mathrm{~B}-\mathrm{C}$ ). At places faint laminae are discerned, probably produced by lateral coalescence of individual laminae and cementation (figure 3B). Phosphate peloids observed here are typically homogeneous, $\sim 300 \mu \mathrm{m}$ size, structureless, rounded to ovular grains and appear

Table 3. Correlation matrix of major elements in the Cretaceous phosphorites.

\begin{tabular}{|c|c|c|c|c|c|c|c|c|c|c|c|}
\hline & $\mathrm{F}$ & $\mathrm{Na}_{2} \mathrm{O}$ & $\mathrm{MgO}$ & $\mathrm{Al}_{2} \mathrm{O}_{3}$ & $\mathrm{SiO}_{2}$ & $\mathrm{P}_{2} \mathrm{O}_{5}$ & $\mathrm{SO}_{3}$ & $\mathrm{~K}_{2} \mathrm{O}$ & $\mathrm{CaO}$ & $\mathrm{TiO}_{2}$ & $\mathrm{Fe}_{2} \mathrm{O}_{3}$ \\
\hline $\mathrm{F}$ & 1.00 & & & & & & & & & & \\
\hline $\mathrm{Na}_{2} \mathrm{O}$ & 0.29 & 1.00 & & & & & & & & & \\
\hline $\mathrm{MgO}$ & -0.41 & -0.25 & 1.00 & & & & & & & & \\
\hline $\mathrm{Al}_{2} \mathrm{O}_{3}$ & -0.50 & -0.34 & 0.44 & 1.00 & & & & & & & \\
\hline $\mathrm{SiO}_{2}$ & -0.50 & -0.27 & 0.58 & 0.88 & 1.00 & & & & & & \\
\hline $\mathrm{P}_{2} \mathrm{O}_{5}$ & 0.45 & 0.35 & -0.51 & -0.49 & -0.50 & 1.00 & & & & & \\
\hline $\mathrm{SO}_{3}$ & 0.06 & 0.28 & 0.26 & 0.07 & 0.06 & -0.05 & 1.00 & & & & \\
\hline $\mathrm{K}_{2} \mathrm{O}$ & -0.25 & -0.25 & 0.67 & 0.33 & 0.48 & -0.29 & 0.10 & 1.00 & & & \\
\hline $\mathrm{CaO}$ & -0.14 & 0.10 & -0.20 & -0.13 & -0.07 & 0.32 & -0.38 & 0.03 & 1.00 & & \\
\hline $\mathrm{TiO}_{2}$ & -0.33 & -0.10 & 0.18 & 0.17 & 0.19 & -0.20 & 0.05 & 0.13 & 0.11 & 1.00 & \\
\hline $\mathrm{Fe}_{2} \mathrm{O}_{3}$ & -0.32 & -0.31 & 0.63 & 0.40 & 0.54 & -0.24 & 0.05 & 0.65 & 0.12 & 0.13 & 1.00 \\
\hline
\end{tabular}



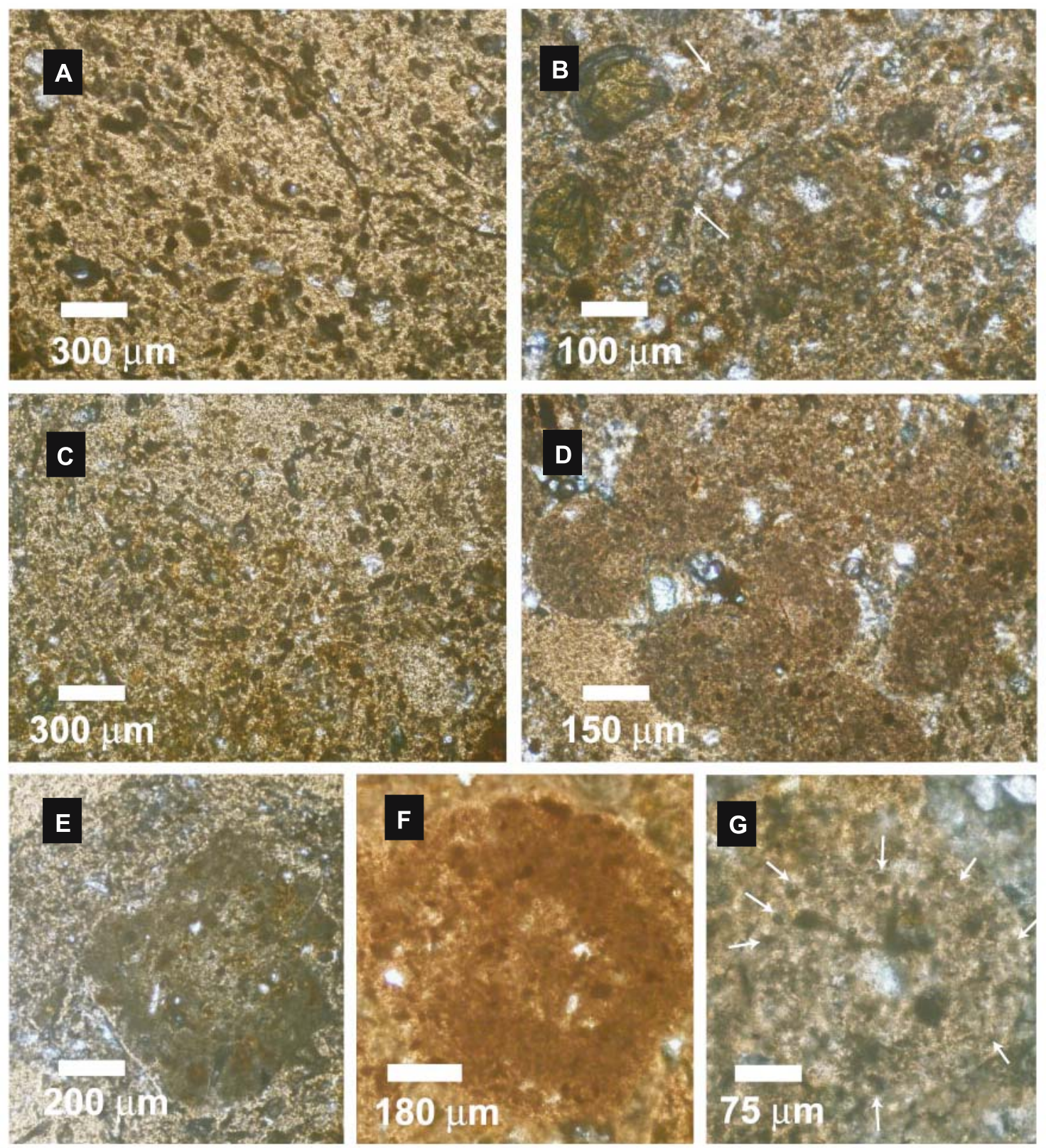

Figure 3. Photomicrographs (thin sections) of Cretaceous phosphorites (A) showing light and dark laminations, (B) peloids and phosphate grains wrapped by filaments (between arrows), (C) algal structure, (D) peloids, (E-G) coated grains. Arrows in figure $3(\mathrm{G})$ show the location of phosphate infillings.

developed locally through mechanical accretion and rearrangement of ground mass in a relatively high energy environment (figure 3D). Phosphate-coated grains (figure $3 \mathrm{E}-\mathrm{G}$ ) surrounded by algal cortex are also common (figure $3 \mathrm{E}-$ G). They exhibit a less porous nucleus circumscribed by thick algal coating and concentric rows of globular phosphate infillings (see arrows in figure 3G). Micro-cracks cut across peloids and other allochems and are filled with calcite and/or celestite. The cortex of the nucleus was largely micritic with silt-sized carbonate and detrital particles.
Scanning electron microscope (SEM) studies on the nucleus of the nodules revealed parallelly aligned phosphate microlaminae of about $3 \mu \mathrm{m}$ diameter (figure 4A). The laminations laterally blurred into a structureless mass of phosphate. The laminae resemble microbial filaments, which appear hollow (figure 4B). The external surfaces of the filaments are either smooth or encrusted by globular phosphate. Elsewhere several submicron size tubules formed the laminae and detrital particles interspersed between the laminae. The laminae wrap around planktonic foraminifer whose calcite was completely replaced by phosphate (figure $4 \mathrm{C}$ ). 

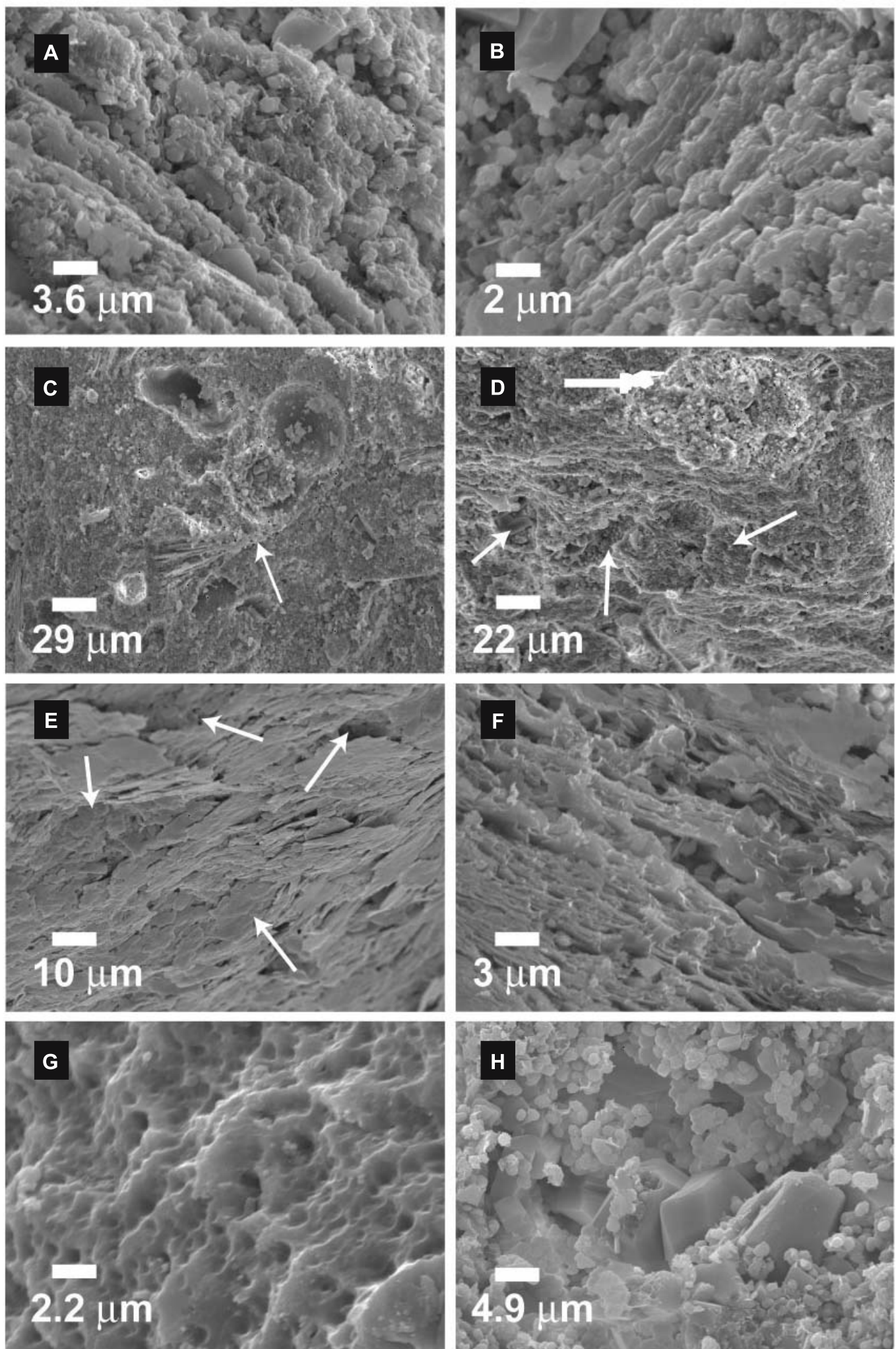

Figure 4. SEM photographs of onshore phosphorites: (A-B) phosphatized micro-laminations, (B) empty microbial filaments (C) planktonic foraminifera wrapped by filaments (see arrow), (D) laminated mat structure (arrows show the location of cavities which were formed by the dissolution of detrital particles; finger shows the location of a cavity filled with phosphate, (E) laminated microbial mat (arrows show the location of moldic vugs of detrital particles); (F) a mat structure showing linearly arranged microbial filaments; (G) microbial cell-based phosphate microstructure; (H) globular phosphatized particles. Calcite crystals can be seen in the centre. 
The detrital particles interspersed between the laminae appear dissolved, leaving hollows (arrows in figure $4 \mathrm{D}$ ) or moldic vugs (see arrows in figure $4 \mathrm{E}$ ) or filled with secondary phosphate precipitates (see finger in figure 4D). Figure 4(F) shows a sheet structure consisting of hollow microbial filaments oriented parallel to one another, resembling microbial mat. A network of hollow, spherical to sub-spherical, $1 \mu \mathrm{m}$-size units set in a phosphatic matrix is another characteristic feature of the nucleus (figure 4G). Phosphate matrix corresponding to apatite globules of about $1 \mu \mathrm{m}$ diameter is also typical (figure $4 \mathrm{H}$ ). The globules resemble fossilized microbial cells reported by several workers (Rao and Nair 1988; Lamboy 1990). The crystalline faces of the globules may indicate transformation of initially formed structures. Sulfide and calcite crystals are also present in the cavities.

\subsection{Mineralogy and geochemistry of the Cretaceous phosphorites}

X-ray diffraction studies of the nodules show that the nucleus consists of carbonate fluorapatite (CFA) as the predominant mineral phase followed by minor calcite. The acid-insoluble residue in the nucleus is about $10 \%$ and consists of quartz and feldspar. The cortex of the nodules shows varying proportions of calcite, followed by CFA, quartz, feldspar and celestite.

Major elements were analysed on thin sections of the nodules by microprobe. The results reveal that the $\mathrm{P}_{2} \mathrm{O}_{5}$ content of the phosphorites ranges from 18 to $26 \%$ and $\mathrm{CaO}$ content from 45 to $57 \%$ (table 2). The average $\mathrm{CaO} / \mathrm{P}_{2} \mathrm{O}_{5}$ ratio of 2.2 is higher than the pure carbonate fluorapatite (1.54). The average $\mathrm{SrO}(0.25 \%)$ and $\mathrm{F}(5.15 \%)$ contents are also higher than that of average phosphorite $(0.07 \%$ and $3 \%$, respectively). The correlation matrix depicted in table 3 indicates that the coefficient of correlation $(r)$ of $\mathrm{Al}_{2} \mathrm{O}_{3}$ with $\mathrm{SiO}_{2}$, $\mathrm{MgO}, \mathrm{Fe}_{2} \mathrm{O}_{3}$ or $\mathrm{K}_{2} \mathrm{O}$ is $\geq 0.5$. The $\mathrm{P}_{2} \mathrm{O}_{5}$ shows a coefficient of correlation of 0.5 with $\mathrm{F}, 0.3$ with $\mathrm{CaO}$ and 0.35 with $\mathrm{Na}_{2} \mathrm{O}$. Correlation coefficients of all other elements with either $\mathrm{Al}_{2} \mathrm{O}_{3}$ or $\mathrm{P}_{2} \mathrm{O}_{5}$ are insignificant.

\section{Discussion}

\subsection{Origin of Cretaceous phosphate stromatolites}

Petrographic and mineralogical observations have revealed that phosphate is the most predominant component in the nucleus of the nodules. The nucleus contains phosphate microlaminae, phosphate grains/peloids and coated grains (figures 3 and 4). Microlaminae comprise several microbial filaments (figure 4D-E). The laminated fabric developed by trapping and binding of detrital particles (see figures 3B, 4C-E) - a strong reminiscent of microbial mat. The sheet structure with linearly arranged microbial filaments in figure $4(\mathrm{~F})$ is also characteristic of microbial mat. Both fungi and cyanobacteria build microbial mats. Microbial filaments described here are straight with no branching (figure $4 \mathrm{~B}, 4 \mathrm{~F}$ ). Since branching is a characteristic feature of fungi, the laminated microbial mat may be related to cyanobacteria. The spherical units shown in figure $4(\mathrm{G})$ may be remnants of microbial cells in a mat and their hollow nature suggests that phosphatization corresponds to the external surfaces of cells. The entire network possibly represents a broken surface of the extra-cellular remnants of the mat-forming microorganisms with a coccoid cellular organization. A similar network was described as biofilm in carbonates by Krumbein (1986). Peloids (figure 3D) appear developed through mechanical accretion and rearrangement of ground mass at in situ conditions. Coated grains, shown in figure $3(\mathrm{E}-\mathrm{G})$, are similar to those in Negev phosphorites (Soudry and Champtier 1983). The concentric rows of globular phosphate infillings in coated grains (figure 3G) are interpreted as globular corpuscles formed due to the colonization of coccoid unicells that subsequently fossilized into cryptocrystalline apatite. Phosphate peloids and coated grains are thus formed at in situ conditions within the mat. Coated grains and a hollow globular network strongly suggest the existence of a mat related to fossilized colonies of coccoid cyanobacteria.

The empty microbial filaments/cell-based phosphate structures imply that the phosphate precipitation on microbial bodies was primary during the metabolic activity of micro-organisms or an early process immediately after their death. These structures are thus interpreted as synsedimentary phosphatized remnants of mat-forming cyanobacteria. The nucleus of the nodules therefore represents phosphate clasts, ripped-up from microbial-mat generated primary phosphorites in high-energy events. Walter (1976) suggested that the trapping and binding of detrital particles by a microbial mat and mineral precipitation because of metabolic activity is the characteristic feature of stromatolites. Therefore the phosphate clasts in the nucleus represent phosphate stromatolites. The phosphate stromatolites described here, however, do not share the macroscopic, columnar habit of many ancient stromatolitic phosphorites of Proterozoic and Cambrian age, abundantly reported globally (Cook and Shergold 1986) and in the 
Himalayan phosphogenic province and peninsular India (Valdiya 1972; Banerjee 1986). Monty (1976) suggested that the stratiform stromatolites with more or less planar laminae are synonymous with cryptalgal laminites. Phosphate stromatolites formed in shallow water settings during the Paleozoic (Bertrand-Sarfati et al 1997), Paleogene (Soudry and Panczer 1994) and Quaternary (Rao et al 2000) and in pelagic settings during Mesozoic along the northern margin of the Mediterranean Tethys (Krajewski et al 1981, 1994; Follomi 1989; Martin-Algarra and Sanchez-Navas 1995) were reported. They suggested that the apatitic stromatolites tend to be composed of minute microlaminated units, which define both the structure and fabric of the authigenic phosphate deposit.

\subsection{Depositional environment of Cretaceous phosphorites}

As indicated above, phosphate stromatolites have been reported both in shallow intertidal environments and in deeper dysaerobic environments. The microbial mats presented here may have colonized the semi-emerged to shallow submerged environments. Such shallow environment is suggested because (a) celestite crystals were encrusted on nodule surfaces (figure 2B) and (b) micro-cracks present in the nucleus and outer carbonate layers of the nodules are filled with calcite and/or celestite (figures 2E, 2H). Micro-cracks may have developed in desiccated conditions during the sub-aerial exposure of microbial mats. Celestites are indicative of their formation in evaporative conditions (Taberner et al 2002). It is therefore likely evaporative, hyper-saline to intermittent exposure conditions prevailed during and/or subsequent to the formation of microbial mats. Moreover, the nuclei of the nodules contain $<10 \%$ acid-insoluble residue and unrecognizable silt-sized carbonate clasts. This indicates that the microbial mats may have developed on or closer to the carbonate substrate wherein intermittent supply of carbonate particles was ensured during mat formation. Keeping in view of the carbonate encrustation around the nucleus (figure 2) and fine-carbonate detritus in the nucleus (figures 3B; 3D), we suggest that the initial mat formation took place on Kallakkudi limestone, underlying the Karai Shale (see table 1). It appears that during high-energy levels the phosphate clasts ripped off from the phosphatized microbial mats, got encrusted with carbonate and celestite and then re-deposited together with various other transported clasts (celestite slabs and Belemnite guards) into the Karai Shale. Therefore, the Karai Shale that formed at relatively deeper water conditions does not represent the actual depositional setting for phosphorite. The episode of phosphogenesis most likely corresponds to the end Kallakkudi Formation which represents shallow platform conditions during AptianAlbian age. In fact, stromatactoid structures, algal biostromal limestones, coral-algal, bryozoan mudstone/wackestones, foraminiferal wackestones were reported in Kallakkudi Formation (Govindan et al 1998). The planktonic foraminifers from these formations may have been transported and deposited with the microbial mats. Pristine phosphate micro-concretions found in organic-rich shales were reported to be reworked in the Upper Cretaceous formations in Egypt (Glenn and Arthur 1990). Similarly, primary phosphogenesis followed by reworking was reported in several Mesozoic phosphorites from the northern Tethyan margin phosphorites (Follomi 1990).

\subsection{Sources of $P$ and process of phosphatization}

The constituents in the phosphorites usually determine the concentrations of major elements. The higher $\mathrm{CaO}$ and $\mathrm{CaO} / \mathrm{P}_{2} \mathrm{O}_{5}$ ratios indicate additional calcite incorporated in the phosphorites. The presence of silt-sized carbonate particles distributed in the matrix support this argument. The actual proportions of $\mathrm{Al}, \mathrm{Si}, \mathrm{Mg}, \mathrm{Fe}$ and $\mathrm{K}$ are low in the phosphorites (table 2). However, significant positive correlation of $\mathrm{Al}$ with $\mathrm{Mg}, \mathrm{Si}, \mathrm{Fe}$ and $\mathrm{K}$ (table 3 ) indicates that these elements are contributed by terrigenous fraction. The negative correlation of $\mathrm{P}_{2} \mathrm{O}_{5}$ with $\mathrm{Al}_{2} \mathrm{O}_{3}$ or $\mathrm{Fe}_{2} \mathrm{O}_{3}$ and very low concentrations of $\mathrm{Al}$ and Fe suggest that the adsorbed phosphate onto mineral surfaces or Feoxyhydroxides released to the pore waters during early diagenesis (Baturin 1981; Berner et al 1993) may not be the principal sources of $\mathrm{P}$ for phosphorite. There is little evidence to support organic productivity associated with upwelling as phosphatization occurred at intertidal settings. As we have proposed phosphate stromatolites, it is most likely that the benthic microbial mats may have supplied $\mathrm{P}$ at the site of formation. Pevear (1966) reported that high phosphorus supply in estuarine to shallow marine environments is due to high productivity of benthic algae. Moreover, cyanobacteria are known to fix high P content. For example, Azad and Borchardt (1970) reported that certain algae are able to fix up to $10 \%$ of $\mathrm{PO}_{4}$ (on a dry weight), thus storing more than twice as much as required for their metabolic needs $(3 \%)$. The microbial filaments and cell structures observed here are empty implying that phosphatization took place during their early stages of decay and before the complete decay of organic matter associated with the mats. The organic matter associated with mucillagenous sheaths of microbial filaments and cells may have 


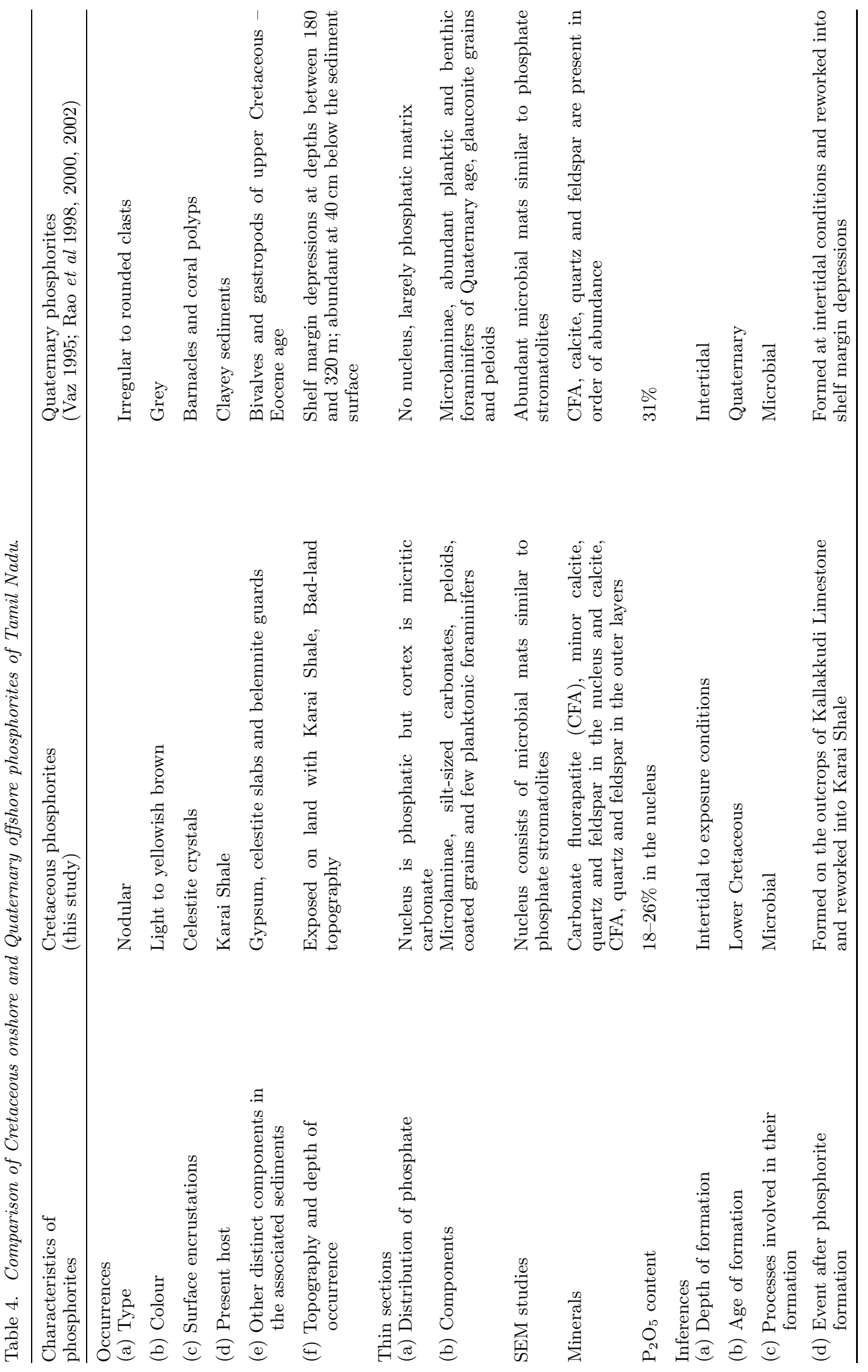




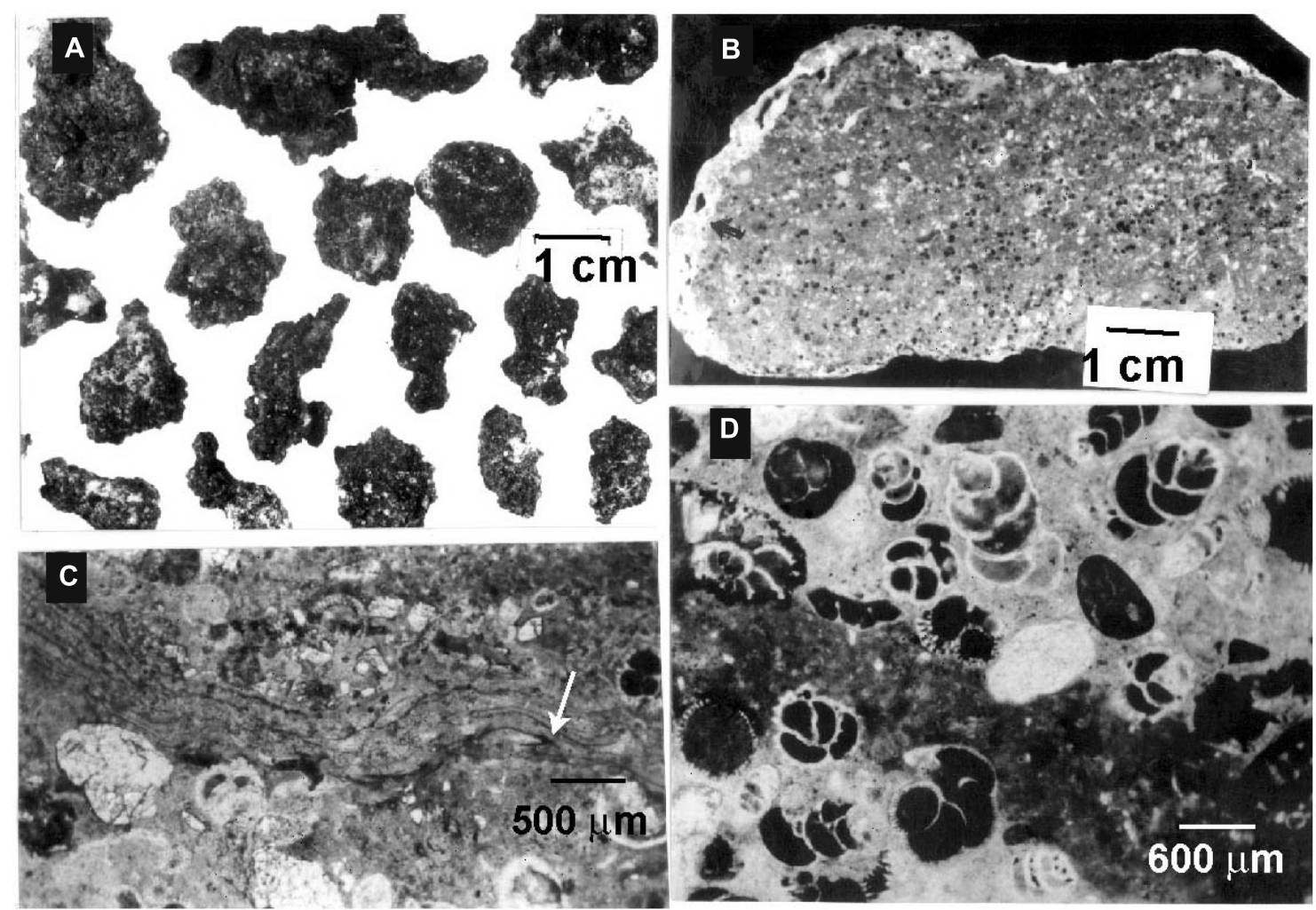

Figure 5. Offshore phosphorites: (A) hand specimens, (B) polished section showing grain-supported texture, (C) thin section showing microbial mat (see arrow) and (D) thin phosphate laminae with adhered detrital particles.

been the source of $\mathrm{P}$ and also acted as a substrate for phosphatization. The decaying bacteria associated with the microbial mats may have assimilated $\mathrm{P}$ and rapidly fixed $\mathrm{P}$ in their structures before getting destroyed. These imply that the microorganisms played an important role in assimilating $\mathrm{P}$, providing microenvironments and precipitating phosphate.

\subsection{Quaternary offshore phosphorites and their comparison with Cretaceous onshore phosphorites}

Vaz (1995), followed by Vaz et al (1999) and Rao et al (1998, 2000, 2002) carried out detailed investigations on petrology, mineralogy and geochemistry of the phosphorites occurring at 180$320 \mathrm{~m}$ depth on the outer continental shelf off Chennai. Table 4 gives the salient features of these phosphorites. They occur as irregular to rounded grey coloured clasts (figure 5A). They exhibit grain-supported texture (figure $5 \mathrm{~B}$ ), consist of microbial mats formed by trapping and binding of sediment particles (figure 5C-D) and are similar to phosphate stromatolites (Rao et al 2000). The constituents incorporated in the phosphorites are glauconitic moulds, and abundant planktic and benthic foraminifers of Quaternary age.
Carbonate fluorapatite, followed by calcite, quartz and feldspar are the mineral phases associated with these phosphorites. They show higher $\mathrm{P}_{2} \mathrm{O}_{5}, \mathrm{SiO}_{2}$, $\mathrm{Al}_{2} \mathrm{O}_{3}, \mathrm{MgO}, \mathrm{Fe}_{2} \mathrm{O}_{3}, \mathrm{~K}_{2} \mathrm{O}$ and $\mathrm{TiO}_{2}$ and lower $\mathrm{CaO}, \mathrm{SrO}$ and $\mathrm{Na}_{2} \mathrm{O}$ than the onshore phosphorites (see table 2).

Onshore phosphorites comprise silt-size carbonates difficult to assign to a particular fossil, while those in the offshore comprise abundant skeletal constituents and glauconitic moulds. The different constituents in the onshore and offshore phosphorites lead to differences in major element chemistry. Onshore phosphorites are of lower Cretaceous age, whereas those in the offshore are Quaternary in age. Although formed at different geological periods, both phosphorite types represent phosphatized microbial mats (phosphate stromatolites) of shallow water settings. At high energy levels these phosphate stromatolites were fragmented into phosphate clasts of different sizes and then reworked into deeper water sedimentary environments, i.e., Karai Shale for onshore and shelf margin depressions with clayey sediments for offshore phosphorites. It is important to note that during the PrecambrianCambrian period stromatolitic ecosystems precipitated abundant carbonate in shallow water settings (Cook and Shergold 1986). But, why did 
similar stromatolitic ecosystems in Cretaceous and Quaternary (reported here) precipitate phosphate in shallow water settings? It may be something to do with the excess phosphorus supply to the localized stromatolitic communities that facilitated the mat-forming micro-organisms to precipitate phosphate directly through microbial processes. The association of late Cretaceous-Eocene bivalve and gastropod shells with the offshore phosphorites may indicate that these fauna together with phosphate clasts were reworked into shelf margin depressions. It is also likely that the chemical weathering of older (Cretaceous-Eocene) formations may have supplied enough $\mathrm{P}$ to the localized microbial mats at shallow shelf settings during the Quaternary. We therefore suggest that abundant benthic microbial production and availability of excess phosphorus at the site are pre-requisites for the formation of phosphate stromatolites in shallow water conditions.

\section{Conclusions}

The Cretaceous phosphorite nodules on the onshore Tamil Nadu revealed that the nucleus of the nodule resembles phosphate stromatolites formed at intertidal conditions. The phosphate stromatolites were disintegrated at high energy conditions and transported to the Karai Shale Formation. The offshore phosphorites of Tamil Nadu are Quaternary in age. They also exhibit phosphate stromatolite characteristics and then reworked as phosphate clasts into shelf margin depressions. Minor differences in the chemistry of the onshore and offshore phosphorites are related to their constituents. It appears that excess phosphorus supply seems to be necessary for the formation of phosphate stromatolites.

\section{Acknowledgements}

We wish to thank the Director of the National Institute of Oceanography (NIO), Goa and the Director, National Geophysical Research Institute, Hyderabad for facilities and encouragement. Mr. Ravi, MCMRD of NIO helped the senior author with thin section photography. We thank the reviewers for their constructive comments. This is NIO contribution 4312.

\section{References}

Azad H C and Borchardt J A 1970 Variations in phosphorus uptake by algae; Environ. Sci. Technol. 4 737-743.

Baioumy H and Tada R 2005 Origin of late Cretaceous phosphorites in Egypt; Cre. Res. 26 261-275.
Banerjee D M 1986 Proterozoic and Cambrian phosphorites regional review: India subcontinent; In: Phosphate deposits of the world, Proterozoic and Cambrian phosphorites (eds) Cook P J and Shergold J H (Cambridge University Press) 1 70-90.

Baturin G N 1981 Phosphorites on the seafloor, origin, composition and distribution; Developments in Sedimentology 33 (Elsevier), $343 \mathrm{p}$.

Berner R A, Ruttenburg K C, Ingall E D and Rao J L 1993 The nature of phosphorus burial in modern marine sediments; In: Interactions of $C, N, P$, and $S$ biogeochemical cycles and global change (eds) Wollast R, Mackenzie E T and Chou L (Springer-Verlag) 365-378.

Bertrand-Sarfati J, Flicoteaux R, Moussine-Pouchkine A and Ahmed A A K 1997 Lower Cambrian apatite stromatolites and phospharenites related to glacio-eustatic cratonic rebound (Sahara, Algeria); J. Sediment. Res. 67 957-974.

Blanford H F 1862 Cretaceous and other rocks of South Arcot and Trichinopoly districts, Madras; Geol. Surv. India Memoir 4217.

Burnett W C and Riggs S R 1986 Phosphate Deposits of the World, v. 3, Neogene to Modern phosphorites (Cambridge: Cambridge University Press) $3464 \mathrm{p}$.

Cook P J and Shergold J H 1986 Phosphate deposits of the World, Proterozoic and Cambrian phosphorites (Cambridge: Cambridge University Press) $1386 \mathrm{p}$.

Follomi K B 1989 Evolution of the Mid-Cretaceous triad: platform carbonates, phosphatic sediments and pelagic carbonates along the northern Tethys margin; Lecture notes in Earth Sciences (Berlin: Springer-Verlag) 23 $153 \mathrm{p}$.

Follomi K B 1990 Condensation and phosphogenesis: example of the Helvetic mid-Cretaceous (northern Tethyan margin); In: Phosphorite Research and Development, (eds) Notholt A J G and Jarvis I, Geol. Soc. Spec. Publ. 52 237-252.

Follomi K B 1994 Concepts and controversies in phosphogenesis; Eclo. Geol. Helv. 87 639-788.

Glenn C R 1990 Depositional sequences of the Duwi, Sibaiya and phosphate formation, Egypt: phosphogenesis and glauconitization in a late Cretaceous epeiric sea; In: Phosphorite Research and Development (eds) Notholt A J G and Jarvis I, Geol. Soc. Spec. Publ. 52 205-222.

Glenn C R and Arthur M A 1990 Anatomy and origin of a Cretaceous phosphorite-Greensand giant, Egypt; Sediment. 37 123-154.

Govindan A, Yadagiri K, Ravindran C N and Kalyanasundar R 1998 A field guide on Cretaceous sequences of Tiruchirapalli Area, Cauvery Basin, India; Oil and Natural Gas Corporation Limited, 53 p.

Krajewski K P 1981 Phosphate microstromatolites in the High-Tatric Albian limestones in the Polish Tatra Mountains; Bull. Acad. Pol. Sci. Ser. Sci. Terre 29 175-183.

Krajewski K P, Van Cappellen P, Trichet J, Kuhn O, Lucas J, Martin-Algarra A, Prevot L, Tewari V V, Gasper I, Knight R I and Lamboy M 1994 Biological processes and apatite formation in sedimentary environments; Eclo. Geol. Helvet. 87 701-745.

Krumbien W E 1986 Biotransfer of minerals by microbes and microbial mats; In: Biomineralization in Lower Plants and Animals (eds) Leadbeater B S C and Riding R (Oxford University Press) 55-72.

Laskar B and Narasimhan A S 1968 Rock phosphate deposits in the Cretaceous rocks of South India; Geol. Soc. India Memoir 2 105-119.

Lamboy M 1990 Microbial mediation in phosphogenesis: new data from the Cretaceous phosphatic chalks of northern France; In: Phosphorite Research and Development 
(eds) Notholt A J G and Jarvis I, Geol. Soc. Spec. Publ. 52 157-167.

Mani G, Srinivasan K R, Nair K B and Selvan T A 1966 A preliminary note on the occurrence of phosphorite in the Uttatur beds of Cretaceous age, Tiruchinoploy district, Madras State; Geological Survey of India report, $30 \mathrm{p}$.

Martin-Algarra A and Sanchez-Navas A 1995 Phosphate stromatolites from condensed cephalopod limestones, Upper Jurassic Southern Spain; Sediment. 42 893-919.

Monty C L V 1976 The origin and development of cryptalgal structures; In: Stromatolites (ed.) Walter M R, Developments in Sedimentology (Elsevier) 20 193-250.

Notholt A J G and Jarvis I 1990 Phosphorite Research and Development; Geol. Soc. Spec. Publ. 52326 p.

Notholt A J G, Sheldon R P and Davidson D F 1986 Phosphate Deposits of the World, V. 2, Phosphate Rock Resources (Cambridge: Cambridge University Press) $566 \mathrm{p}$.

Pevear D R 1966 The estuarine formation of United States Atlantic coastal plain phosphorites; Econ. Geol. 61 251-256.

Rama Rao L 1958 Fossil Algae in India; Nature 181 $544-545$

Rao V P and Nair R R 1988 Microbial origin of phosphorites of the western continental margin of India; Mar. Geol. 84 $105-110$.

Rao V P, Rao K M and Raju D S N 2000 Quaternary phosphorites from the continental margin off Chennai, southeast India: Analogs of ancient phosphate stromatolites; J. Sediment. Res. 70 1197-1209.

Rao V P, Rao K M, Vora K H, Almeida F, Subramaniam M M and Souza C G A 1998 A potential phosphorite deposit on the continental margin off Chennai; Curr. Sci. 74 577-579.

Rao V P, Michard A, Naqvi S W A, Bottcher M E, Krishnaswamy R, Thamban M, Natarajan R and Borole D V 2002 Quaternary phosphorites off the southeast coast of India; Chem. Geol. 182 483-502.

Sastry V V, Raju A T R, Sinha R N and Venkatachala B S and Banerjee R K 1977 Biostratigraphy and evolution of the Cauvery Basin, India; J. Geol. Soc. India 18 $355-377$.

Soudry D and Champetier Y 1983 Microbial processes in the Negev phosphorites (southern Israel); Sediment. 30 411-423.

Soudry D and Panczer G 1994 Stromatolitic phosphorites in the Eocene of the Negev (Southern Israel); In Phanerozoic stromatolites II (eds) Bertrand-Sarfati J and Monty C L V (The Netherlands: Kluwer) 255-276.

Taberner C, Marshall J D, Hendry J P, Pierre C and Thirlwall M F 2002 Celestite formation, bacterial sulphate reduction and carbonate cementation of Eocene reefs and basinal sediments (Igualada, NE Spain); Sediment. 49 $171-190$

Valdiya K S 1972 Origin of phosphorite of the late Precambrian Gangolihat dolomites of Pithoragarh, Kumaun Himalaya, India; Sediment. 17 115-128.

Vaz G G 1995 Phosphatic nodules in the outer continental shelf off Madras, Bay of Bengal; Indian J. Mar. Sci. 24 $8-12$.

Vaz G G, Vijay Kumar P and Rao B L 1999 Phosphorites from the continental margin off Madras, Bay of Bengal; Mar. Georesour. Geotechnol. 17 33-48.

Walter M R 1976 Stromatolites; Development in Sedimentology (Amsterdam: Elsevier) 20790 p. 